\title{
EL POETA COMO DIRECTOR: DIEGO MAQUIEIRA Y EL CASO ANNAPURNA
}

\author{
Gustavo Quintero Vera \\ University of Pittsburgh \\ Pittsburgh, Estados Unidos \\ Geq2@pitt.edu
}

\section{RESUMEN / ABSTRACT}

El siguiente trabajo analiza la propuesta de El Annapurna (2013), del poeta chileno Diego Maquieira. Por medio del uso de la técnica del montaje (tanto en su acepción "cinematográfica" como de "fotomontaje"), Maquieira dota al texto intervenido de una lógica próxima a la imagen. A partir del sentido de recomposición (destructivo-constructivo), el montaje desencadena una desarticulación textual profunda. Como consecuencia, hay una suspensión o interrupción constante, que se verá reflejada en la temporalidad de la imagen, las voces quebradas y en el sentido general anulado del texto. Por este medio, la imagen no busca substituir un texto fallido, sino crear las condiciones de posibilidad para hacer emerger "otro" sentido.

Palabras clave: Diego Maquieira, poesía visual, texto e imagen, montaje, imagen pensativa.

THE POET AS DIRECTOR: DIEGO MAQUIEIRA AND THE ANNAPURNA

This article analyses the poetry book El Annapurna (2013), by the Chilean poet Diego Maquieira. By way of the technique of montage (in both its "cinematic" and "photomontage" connotations), Maquieira intervenes his text and has it work in a manner close to a visual logic. From that point forward, the deconstructive-constructive action of montage unleashes a profound sense of textual disarticulation. This will result in a constant interruption or suspension reflected in the time of the image, in the broken voices and the general annulation of meaning in the text. Thus, the image does not look to substitute a failed text, but to create the conditions of possibility to give way to the emergence of another meaning.

KEYWORDS: Diego Maquieira, visual poetry, text and image, montage, pensive image. 
Diego Maquieira escribe dos libros únicos, brillantes, y después opta por el silencio. ¿Qué nos quiso decir Maquieira?, me pregunto a veces. ROBERTo Bolaño, "La poesía chilena y la intemperie"

No rompas el silencio rompe la palabra. Haz con los pedazos un silencio nuevo. Diego Maquieira en conversación con Bruno Cuneo

En el libro Give me a break: conversaciones con Diego Maquieira (2008), Patricio Hidalgo y Daniel Hopenhayn entablan una serie extensa de diálogos con el poeta Diego Maquieira (1951), que iluminan de primera mano su vida, obra e intereses estéticos. Las entrevistas tienen lugar en el año 2005, al menos una década después del que era, en ese momento, el último poemario publicado de Maquieira, Los Sea Harrier (1993), y también, alrededor de un año después de haberse internado por voluntad propia en una clínica psiquiátrica para tratar su alcoholismo crónico. En una conversación en la que, según los jóvenes investigadores, el poeta estaba más entusiasmado de lo común, este toma las riendas de la discusión, dándole inicio de la siguiente manera:

Empecé a darme cuenta de que era urgente inventar o crear o descubrir un nuevo sistema de composición poética, porque con lo que hasta ahora tenemos no podemos seguir avanzando, estamos en un pantano. Eso es lo que necesito hacer: develar un nuevo sistema de escritura para poder salir del atolladero en el que estoy, y creo que otros también deben estar en lo mismo (Hidalgo y Hopenhayn 263).

Si bien el autor aquí, en principio, se refiere al modo en el que se estaban llevando a cabo las entrevistas, esta afirmación revela una preocupación recurrente en el pensamiento de Maquieira. Nuestro poeta se encuentra sumido en un largo proceso de revaloración de los medios de creación poética que durará años y que verá su expresión máxima en la que es, hasta el día de hoy, su última entrega: El Annapurna (2013).

Por lo menos desde la publicación de Los Sea Harrier, Maquieira se ha definido a sí mismo una y otra vez como "director" o "compositor" de 
poesía $^{1}$. Esta postura toma un impulso renovado a partir de la publicación de El Annapurna. Por ahora, limitémonos a ver a qué se refiere con esta sugerente imagen. Ante la pregunta de cómo llega al concepto de "director de poesía", Maquieira responde lo siguiente:

Para distanciarme del yo poético, para tomar una distancia. Me gustó mucho la idea de componer como si fuera un músico o un director de cine, que filma, filma, y después editing, editar. Me gustó mucho esa distancia, por sus posibilidades de trabajar con un gran angular. Los demás te dicen poeta para orientarse, pero la idea de ser director de poesía me atrae mucho. Yo llevo el cine a la poesía, porque siempre he tratado de que mis poemas se vean (Hidalgo y Hopenhayn 191).

Dicho de otro modo, Maquieira no piensa la figura del poeta como el que suscita un yo poético exclusivamente a través de la palabra, sino, al modo de Juan Luis Martínez, como el que se borra, difumina y expande las funciones tradicionales de la poesía. Sin duda, esta postura se relaciona directamente con una consciencia del desgaste de la palabra poética y la búsqueda de métodos alternativos para articular la poesía. En 2013, Maquieira declaraba en una entrevista que "[e]1 lenguaje está saturado, solo queda el repertorio" (González Ríos párr. 23). Además, en Give me a break hay un poema suyo, sin titular, cuyos versos dictan que
Nos estamos muriendo aplastados
por el exceso de repertorios
y la escasez de registros.

\footnotetext{
David Bordwell y Kristin Thompson definen al director de cine en términos cercanos -aunque no del todo idénticos-a "la teoría del autor" popularizada por los críticos de Cahiers du Cinéma. Para estos críticos franceses, el director es la fuerza unificadora o decisiva detrás de un film, es quien más control ejerce sobre él aunque otros aporten en el proceso y, según esta lógica, es el único "autor" de la obra. Bordwell y Thompson mencionan que, "[a] pesar de las dificultades y la variedad de los enfoques, una versión de la postura 'director como autor' sigue siendo probablemente la asunción más ampliamente compartida en los estudios sobre cine de hoy en día" (38). Aun así, ellos optan por concebir al director más bien como una marca de estilo: "El autor ya no es una 'persona', sino, en lo referente al análisis, un sistema de relaciones entre varias películas que llevan la misma firma" (ibid.). Como veremos más adelante, ambas definiciones aplican al director como lo concibe Maquieira.
} 


\author{
Pound \\ Pope \\ Poe \\ Po (Hidalgo y Hopenhayn 261).
}

Más allá del característico afán lúdico que siempre ha definido la producción de Maquieira, tanto la primera afirmación como el poema que le sigue ilustran una preocupación sostenida y, hasta cierto punto, literal, con el desgaste de la palabra poética. Grandes nombres de la poesía universal conviven en el espacio del poema, desgastándose hasta llegar a la expresión "Po", un simultáneo juego de palabras entre el nombre del poeta Li Po y la muletilla más característica de la lengua coloquial chilena. Para distanciarse, entonces, de un lenguaje petrificado, muerto y deteriorado, el poeta tratará de encaminarse por nuevas rutas que lo volcarán cada vez más cerca del universo de la imagen.

Por cierto, no es ninguna coincidencia que Maquieira aspire a exceder la palabra poética. A partir de Baudelaire, Mallarmé y la tradición modernista anglófona, la cultura occidental ha sido testigo de una constante crisis del verso que ha desencadenado los experimentos vanguardistas de la primera mitad del siglo XX, que se prolongan hasta nuestros días. Sin embargo, esto no quiere decir que el poeta se dé por vencido; la indagación por la experiencia poética continúa, hoy y siempre, por otros medios. La encrucijada en contra del lenguaje poético tradicional en Maquieira es evidente desde sus primeras dos publicaciones: Upsilon (1975) y Bombardo (1977) ${ }^{2}$. Aunque de escasa circulación, estas obras prepararon el camino para la "escritura inclasificable" (Rioseco 247) de los dos poemarios más conocidos de Maquieira, La Tirana (1983) y Los Sea Harrier. Tanto así, que el crítico Marcelo Rioseco ha señalado que "la movilización imaginario-fantástica de Los Harrier depende de la elección de los elementos, de su composición y de su idea poética, y no de estímulos literarios verbales implicados en el esquema material del texto" (296-97). Maquieira descoloca y desautomatiza no solo a través de su filiación subrepticia con el desparpajo y la cotidianidad temática de la antipoesía de Parra, sino -principalmente- por la combinación de su puesta

2 Upsilon es un poemario influenciado, entre otros, por la poesía concreta brasileña, mientras que Bombardo es una suerte de proto-Annapurna: un poema-collage, de escasas páginas, hecho a base de imágenes y palabras. 
en escena lúdica y su dinámica imprevisible. Rioseco interpreta la poesía de Maquieira como una "máquina carnavalesca" que, a través del juego -de nuevo, tanto lingüístico como a nivel de su puesta en escena-, logra entablar "una guerra contra la moral anquilosada del dogma ordenador de la sociedad chilena de esos años y los anteriores" (256). Bajo este lente, la escritura previa de Maquieira adquiere una consistencia iconoclasta que refleja un trabajo elaborado y consciente en contra de cualquier facilismo con la palabra, del que será heredero El Annapurna.

A continuación, analizamos un poemario (El Annapurna) en el que la técnica del montaje ayuda a dotar el texto de una lógica cercana a la imagen. Aquí nos referimos al término "montaje" en su doble sentido, tanto en su acepción de "montaje cinematográfico" (el ensamblaje de secuencias a partir de planos individuales) como la de "fotomontaje" (la creación de una imagen a partir de la manipulación, combinación o yuxtaposición de otras, como en varias versiones del collage). Técnica privilegiada por los movimientos de renovación artística de las primeras décadas del siglo XX -los collages cubistas, los fotomontajes futuristas, dadaístas, surrealistas y constructivistas y las teorías fílmicas soviéticas de finales de los años $20-^{3}$, en todas sus diferentes versiones el montaje comparte "a wide array of practices premised on quoting, combining, and juxtaposing materials that straddle the bounds of old and new media-from literature and stage drama to painting, sculpture, photography, film, and radio" (McBride 14). En este sentido, intentamos trazar "la forma en que los textos actúan como imágenes o 'incorporan' la práctica pictórica y viceversa” (Mitchell 12). Por ello, no nos concentramos en delinear exclusivamente los usos literales de la fotografía y la imagen en estos textos -aunque esto también sea importante-, sino en desentrañar los procesos que aproximan su lógica a la imagen. A partir del sentido de recomposición (destructivo-constructivo), el montaje desencadena una

3 El efecto y fin del montaje en un medio como el cine no es el mismo que en la fotografía o la pintura. El montaje es el procedimiento técnico constitutivo del medio cinematográfico (todo cine es montaje, lo que cambian son los modos de su implementación [p. ej. narrativo, dialéctico, etcétera]). En el collage cubista esta técnica busca incorporar pedazos de periódico u objetos reales en el cuadro para cerrar la brecha entre la obra de arte y el mundo. A diferencia de los cubistas, en el fotomontaje dadaísta la imagen fotográfica se usa como el principal material estructurador del cuadro, que combinado con recortes de periódicos y revistas, tipografías y dibujos tiene la intención de llevar a cabo "un provocador desmembramiento de la realidad" (Ades 14). 
desarticulación textual profunda. Como consecuencia, hay una suspensión o interrupción constante, que se verá reflejada en las voces quebradas y en el sentido general anulado del texto. Por este medio, la imagen no busca substituir un texto fallido, sino crear las condiciones de posibilidad para hacer emerger "otro" sentido. En Ante el tiempo (2016), Didi-Huberman argumenta que el tiempo de la imagen corresponde a una temporalidad sincopada, impura, con pliegues y ritornelos. Las dislocaciones temporales y secuencias discontinuas que proliferan en los próximos ejemplos deben ser medidas bajo este lente.

El concepto de "director de poesía" sugiere que la escritura de Maquieira está influenciada por la composición musical, el cine y la pintura -él mismo es pintor y tiene varias exposiciones bajo su nombre-. Los motivos visuales y lingüísticos que recorren el libro van a darnos las pautas para establecer ritmos, intensidades y conexiones subterráneas entre elementos del texto. Quizás sea en este sentido que podemos interpretar el título de la obra, ya que como indica su autor: "Me gusta la idea de que el Annapurna es un amigo que tiene el Aconcagua en el extranjero. Es un amigo muy fértil, muy múltiple, muy sibarita. Y el Aconcagua es un asceta, un monje en la montaña, un cenobita, es un ermitaño. Y son íntimos amigos"("Diego Maquieira - El Annapurna", 2:25-2:45 min.). El cerro Aconcagua, uno de los picos más altos del mundo, se encuentra ubicado en la cordillera de los Andes, entre la frontera de Chile y Argentina. En la concepción poética de Maquieira, este cerro se comunica subrepticiamente con el Annapurna, una de las montañas más altas del Himalaya. Distintos en su carácter pero con vasos dialogantes que los conectan, cada uno crea ecos del otro, aun dentro de sus diferencias. Es decir que se comunican a pesar de su heterogeneidad. El esfuerzo de Maquieira se aboca a encontrar resonancias entre disímiles y tensarlos para llevar al espectador a través de un recorrido del campo visual.

El Annapurna surge de prácticas que el autor asume en un periodo en el que queda al borde de la ceguera. Durante su recuperación, Maquieira visita con frecuencia librerías y bibliotecas de barrio, fotocopiando álbumes de fotografía y enciclopedias con el fin de crear un archivo propio de imágenes. A partir de esta práctica privada comienza a desplegar un proyecto nuevo, que tomará forma a finales del año 2012, gracias a la gestión del poeta y crítico, Ronald Kay, el director de la galería D21, Pedro Montes, y el curador de la Bienal de São Paulo, Luis Pérez-Oramas (Zúñiga párr. 15). El proyecto se presenta por primera vez en la XXX Bienal de São Paulo, en 2012, y el año 
siguiente aparece publicado en una edición de libro de autor, con una tirada limitada a 500 copias coordinada por D2 $1^{4}$.

El subtítulo de El Annapurna es "Poemaducto de imágenes de conocimiento público en fotocopias (2007-2012)". "Poema-ducto", como un conducto o un canal de imágenes interconectadas que dan pie a un poema. Desde un principio, Maquieira pone sobre el tapete su método de composición y creación: el montaje de un archivo de imágenes de conocimiento público intervenidas con la palabra y la mano del autor. Este es un gesto paradójico: cuando Maquieira afirma que su intención es distanciarse del yo poético, una de las formas que tiene para lograr esto es por medio de las imágenes. Las fotografías y los cuadros que integran El Annapurna son tomadas o hechas por otras personas y forman un collage de otras voces/ojos. Sin embargo, al seleccionar e intervenirlas con su puño y letra, es decir, al "dejar su huella" en ellas, ¿está Maquieira reafirmando su voz autoral o está haciendo otra cosa? Pensemos primero en el doble movimiento que estructura el libro: la selección de imágenes y su ordenamiento (que resignifica por la puesta en relación con otras imágenes y la recirculación de imágenes), y la inscripción a mano (que resignifica por medio de un repertorio amplio de chistes, juegos de palabras, palabras extranjeras y referencias culturales universales). Lo primero tiende analogías entre imágenes, sintetiza y une, mientras que los comentarios irónicos, paródicos y descontextualizaciones tienden al quiebre y la irrupción del régimen lingüístico en el visual. Esta tensión es clave y volveremos a ella en breve.

Lo que está en juego en el acto de selección es una postura, una relación frente a la tradición y el archivo. En Archive Fever (1995), Derrida desarrolla una teoría del archivo a partir de la tradición psicoanalítica freudiana y sus instituciones. En esta concepción, el archivo es un espacio donde se encuentran fuerzas contradictorias en constante estado de tensión y lucha. El archivo tiene el poder de instaurar una tradición y conservarla, pero simultáneamente detrás de este gesto siempre hay un impulso generalizado hacia la destrucción [death drive] y supresión del archivo. Espacio de lucha por excelencia, el

\footnotetext{
Existe un registro de la presentación-performance del proyecto, en la que Maquieira declama un poema de Los Sea Harrier frente a la puesta física del Annapurna. A diferencia de cómo aparecen posteriormente en el libro, en la Bienal de São Paulo las fotos están colgadas en secuencia, una al lado de la otra, sobre un muro de 15 metros. Para más información, consultar el video “\#30bienal (Programação) Diego Maquieira: Poesia fora de circuito". Youtube. 14 de diciembre de 2012. Disponible en: https://youtu.be/BHu1kr5TdqU
} 
archivo intenta organizar e imponer un límite (finito y ficticio) a una serie potencialmente infinita; en otras palabras, el archivo ejerce un corte consciente $\mathrm{y}$, al mismo tiempo, trata de suprimir la memoria de ese primer corte para naturalizar su propia existencia. Es por esta razón que, a pesar de contar con un principio de economía que apunta hacia la preservación de información, el archivo está siempre ante la posibilidad muy real de pérdida, amnesia y olvido. Como objeto teórico, la deconstrucción de la noción de archivo presenta una oportunidad para cuestionar la fijeza ilusoria y la pretendida objetividad que encarna el archivo. Así, es posible entenderlo como un espacio dinámico, en construcción, nunca cerrado y sedimentado. Consciente de estas dinámicas, Maquieira se ha referido varias veces a El Annapurna como una "obra abierta", nunca terminada. Esto es palpable en cualquier conversación con el poeta: con frecuencia, este añade notas adicionales a mano en cada copia individual, creando así el sentimiento de que esta es una obra viva, en proceso constante.

Es válido ahora preguntar: ¿qué valor tiene hoy un gesto tan "tradicional" como la construcción de un archivo? En cuanto al valor artístico del acto de selección y el amplio repertorio de gestos de resignificación que lleva a cabo Maquieira, se puede decir que esta postura refleja una tendencia generalizada en el campo artístico actual. Joan Fontcuberta, por ejemplo, afirma que vivimos en una época de "inflación de imágenes sin precedentes" (7). Su libro estudia cómo esta particular "furia" modifica nuestra relación con las imágenes, además de los cambios en funciones y los efectos que dicha propagación tiene sobre la creación artística. La condición postfotográfica se relaciona con la desmaterialización de la imagen, su circulación irrefrenable en las redes, la proliferación de los dispositivos móviles y la consecuente democratización y secularización de la imagen. El impacto que estas nuevas tecnologías tienen sobre la creación artística es complejo y merece una discusión amplia. Para los efectos de esta lectura rescatamos solo algunas premisas que el crítico expone en su "Decálogo postfotográfico":

1. Sobre el papel del artista: ya no se trata de producir "obras" sino de prescribir sentidos.

2. Sobre la actuación del artista: el artista se funde con el curador, con el coleccionista, con el docente, con el historiador, con el teórico... Todas estas facetas son camaleónicamente autorales.

3. Sobre la responsabilidad del artista: se impone una ecología visual que penalizará la saturación y alentará el reciclaje. 
4. Sobre la función de las imágenes: la circulación de la imagen prevalece sobre el contenido de la imagen (Fontcuberta 39).

Cada punto aquí expuesto puede ser entendido como una propuesta de principios que estructura El Annapurna. Maquieira selecciona imágenes de un repertorio universal (es una suerte de "coleccionista-curador"), las "recicla" en un nuevo proyecto (parte de la creación previa, las hace circular nuevamente), las organiza y las interviene a mano ("prescribe nuevos sentidos"). No queremos insinuar que Maquieira esté apoyándose en las postulaciones de Fontcuberta -al contrario, este no es un proyecto postfotográfico en sí mismo-, pero queremos sugerir que en este caso el artista está sintonizado con las tendencias que estructuran el campo fotográfico contemporáneo y que aplica sus técnicas, a su propio modo, en su proyecto literario. El artista ya no se limita a producir nuevos contenidos en un sentido clásico, sino que, como afirma Maquieira, existe un repertorio exorbitante (sea de palabras o de imágenes), sobrecogedor y furioso, el cual debe ser minado y reconfigurado. No obstante, es importante recalcar que la estética postfotográfica en sí misma no es única ni original, ya que recupera valores conocidos de momentos clave de la historia del arte del siglo XX: basta nombrar el ready made duchampiano, el objet trouvé surrealista, los fotomontajes de John Heartfield, el pop art de Andy Warhol, o bien, en el campo de la literatura, la estética de Borges en "Pierre Menard, autor del Quijote" (1939), para entender de dónde provienen algunos de los procedimientos formales que sirven de influencia para estas nuevas olas del arte contemporáneo.

Pese a mirar hacia el pasado para reorganizarlo, el archivo siempre está dispuesto hacia el futuro. El Annapurna está mirando hacia el futuro, hacia un espacio en el que el autor pueda escapar de la cárcel del lenguaje y encarar su proceso de recuperación. Nada más certero que la imagen de la portada y contraportada para entender esta dinámica. La portada [Imagen 1] establece un puente con la obra previa de Maquieira, ya que funciona como un guiño visual al poemario Los Sea Harrier, poema "épico" o "cinematográfico" (Joannon y Donoso cit. en Rioseco 254) que ilustra la lucha campal entre dos bandos: los milenaristas y los Harriers. En el poemario, los rebeldes libertinos que pilotean los Harriers se encuentran en el escenario del cielo contra la posma milenarista y sus aviones Mig y 
Mirage. La imaginería naval y barroca central del libro anterior reaparecerá en numerosas ocasiones a lo largo de esta nueva entrega 5 .

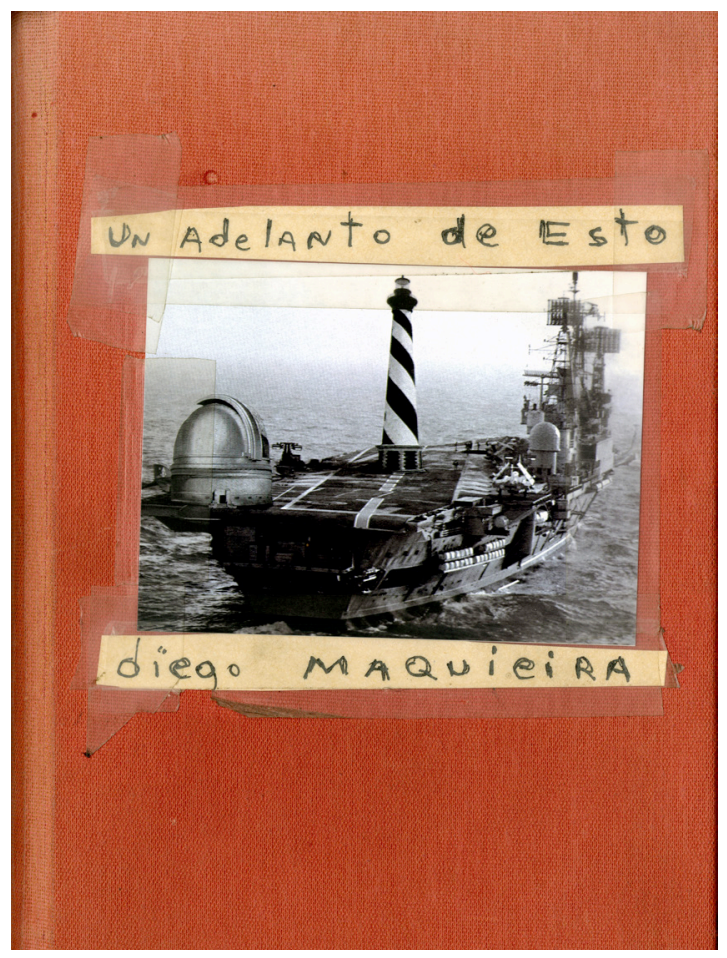

Imagen 1. Portada de El Annapurna ${ }^{6}$

$5 \quad$ Por ejemplo, la imagen de la portada es una referencia visual al poema "Levantamos un faro" de Los Sea Harrier: "Levantamos un faro en medio del mar / un faro de papeles de papiro / que usábamos para guardar los vinos / y para echarnos a beber con mujeres / pero no hacíamos nada para la posteridad / [...] Ma a veces maravillados por un Mirage / por una clona que nos hacía los ojos / asaltábamos a la sexta flota española / y promovíamos grandes desórdenes bajo cubierta / Pero no hacíamos nada grande la verdad / Abusábamos del amor / del ocio y del porvenir / y bebíamos hasta moverle el piso al mar" (97).

$6 \quad$ Las páginas de El Annapurna no están enumeradas y las imágenes tampoco llevan títulos ni se constata su lugar de origen. El mero acto de no numerar dinamita muchas funciones tradicionales del texto lingüístico: implica que no hay que seguir la linealidad ni la cronología del texto verbal. Los pie de foto que figuran de aquí en adelante son del autor del presente estudio. 
Más allá de las resonancias de la obra previa, resulta central aclarar que, dada la condición física de Chile -un país extremamente estrecho, aunque casi del largo de un continente, encarcelado física y simbólicamente por la cordillera de los Andes-, la voz popular dicta que los chilenos miran siempre para dentro de sí y dan la espalda al resto de América Latina. En el fotomontaje de la portada observamos la fotografía de un portaviones en alta mar, en cuya cubierta están sobreimpuestos un faro y un telescopio. Ambas construcciones, faro y telescopio, son características de Chile, pero dependen forzosamente de su conexión con la tierra firme. Con su técnica de fotomontaje, Maquieira parece estar diciendo que, en lugar de mirar para dentro, el artista debe subvertir su lugar en el mundo y convertir estas construcciones típicamente chilenas y fijas en estructuras móviles, vueltas hacia el encuentro del otro. La disposición del portaviones, junto con la frase "Un adelanto de Esto", da la impresión de mirar hacia el horizonte, hacia el mar y el futuro. La apertura del mar representa, entonces, el inicio de la aventura y todo lo que está por venir: es el campo de posibilidades que se abre al dotar de movilidad a los referentes simbólicos de la patria. Al mismo tiempo, se libera el referente en el uso del pronombre demostrativo "Esto". "Esto" queda suspendido en el aire, vacío, sin apuntar a un referente claro, hasta dar vuelta la solapa y recaer en la fotocopia en blanco y negro de una pintura de Balthus de una chica joven reclinada en un sillón ("Thérèse" [1938]), con la palabra "Esto" y el nombre del autor escritos en tinta azul:

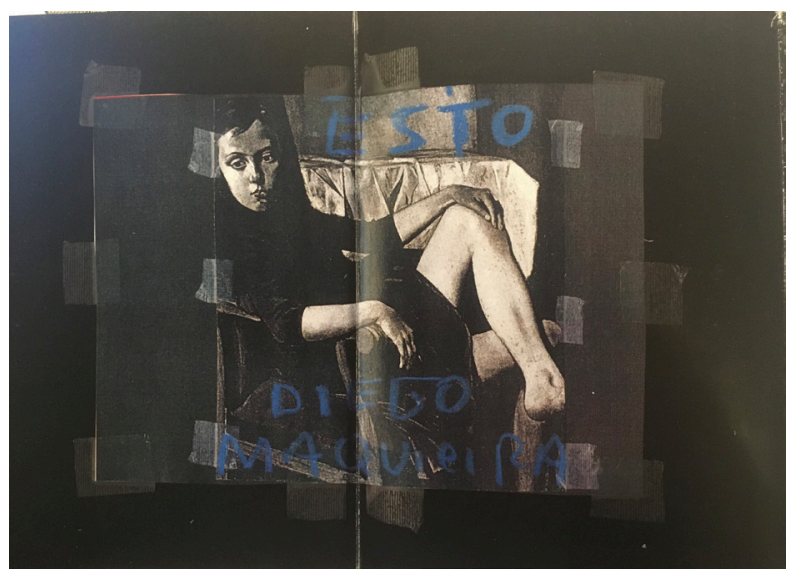

IMAgen 2. Solapa de El Annapurna 
La portada, como el lugar simbólico por excelencia que es, funge de carta de presentación, esgrimiendo técnicas que apuntan hacia la suspensión momentánea del sentido en aras de la creación de nuevos diálogos y posibilidades en la imagen. Aunque la imagen de la portada es un fotomontaje, en el sentido de la construcción de una fotografía a partir de la yuxtaposición de otras, la aplicación de esta técnica no es recurrente a lo largo de El Annapurna, por lo menos no en este sentido tan limitado. Lo que sí observamos con frecuencia es el uso del fotomontaje entendido como la intervención textual sobre fotografías. Una obra como "Bloomfield presidente Dadá-chaplinista" (1921), de Erwin Blumenfeld, tiene claros ecos en la combinación de imagen y texto que tiene lugar en este poemario. Como adelantamos al inicio, y como se desprende de este ejemplo, nos interesa evocar una doble dimensión del montaje: primero, en un sentido cercano al cinematográfico, es decir, en tanto la creación de secuencias a partir de fragmentos más pequeños; $y$, segundo, en una versión micro, en tanto intervenciones singulares del texto sobre la imagen.

En la parte inferior de la página que sigue al título figura el mensaje: "Portada del cuaderno original de punto de partida // Tiempo de observación de lectura indefinido // Banda sonora no incluida / agregada a elección del observador". Con estas escuetas instrucciones el lector-espectador, de entrada, es puesto en un lugar incómodo. Nos podemos preguntar, entonces, ¿qué es El Annapurna? ¿Estamos frente a un libro, un libro álbum, un libro-objeto, una obra multimedia, u otra cosa que aún no entendemos? Más importante que definir taxonómicamente este libro quizás sea entender el hecho de que nos adentramos en un proyecto que se inserta dentro de otra lógica: la lógica de la imagen que, en última instancia, se relaciona con un arte del tiempo. Por esa razón, y bajo esa lógica, es que la dedicatoria general está dirigida: "A todas aquellas / mentes preciosas / y espíritus de primer orden / que inventaron la escritura con luz / y develaron / la transfiguración del tiempo / a través del ojo de la aguja". El tiempo de observación de lectura indefinido sugiere un escape de los esquemas tradicionales de lectura de un texto verbal y la sumersión en los tiempos de la imagen. Es decir, el tiempo de lectura continuo y sucesivo de un texto verbal se intercambia aquí por el tiempo indefinido, quebrantado, no-secuencial y transfigurado de lo visual.

Maquieira está consciente de las dificultades que esta postura puede presentar para el lector promedio de poesía. Aun así, no duda en ubicar su texto en una larga tradición de poesía visual chilena e internacional, donde su obra se complementa con "los poemas pintados de Huidobro, los 
Artefactos de Parra, los poemas en el cielo de Zurita, el Quebrantahuesos, la obra de J.L. Martínez, los dibujos de Zeller, Bertoni, [...] la poesía concreta, el Atlas de Warburg, Richter, Malevich, Benjamin y Warhol" (González Ríos párr. 22). Los ecos del Atlas Mnemosyne aquí son particularmente importantes, no solo porque la puesta en escena de El Annapurna en la Bienal de São Paulo recuerda la disposición en tablas del proyecto póstumo del historiador de arte alemán, sino porque ambos proyectos están enmarcados por preocupaciones similares. Las supervivencias [Nachleben], que Warburg denominó "el problema capital" de su pensamiento (Didi-Huberman, La imagen 74), representan una memoria social e inconsciente de las formas a través del tiempo. El tipo de memoria que Warburg adjudica a las imágenes se estructura en torno a otro tiempo irregular, sincopado, lleno de latencias, un "tiempo psíquico" (Didi-Huberman, La imagen 253) distinto del que dicta la cronología histórica. El modelo que mejor describe los ritmos y el funcionamiento de las supervivencias es el síntoma histérico, como lo define y conceptualiza Freud. La teoría del síntoma se caracteriza por un retorno de lo reprimido. En un momento dado de la vida del sujeto ocurre un trauma que debe ser reprimido por el inconsciente y este permanece latente por un tiempo indefinido. En el momento de crisis histérica, el síntoma se actualiza de modo contradictorio. Freud cita el ejemplo de un ataque histérico en el que "la enferma mantiene con una mano su ropa apretada contra el cuerpo (como mujer), mientras que con la otra trata de arrancársela (como hombre)" (cit. en Didi-Huberman, La imagen 268). Este tiempo psíquico desarticula las nociones de pasado, presente y futuro que estructuran la historia general. El recorrido de El Annapurna apela a esta suerte de inconsciente visual marcado por obsesiones y reapariciones de las formas, por estratos, bloques híbridos y rizomas, pero lo hace no ya desde el punto de vista de un "modelo cultural de la historia", sino desde la visión poética. En parte, por eso este libro puede ser entendido como un mapa de las afinidades intelectuales de Maquieira, como si todo el proyecto fuera una máquina para recolectar resonancias magnéticas poéticas al estilo del diálogo imaginario que entablan el Annapurna y el Aconcagua, creando vasos dialogantes que conectan entre sí a pesar de sus diferencias. 


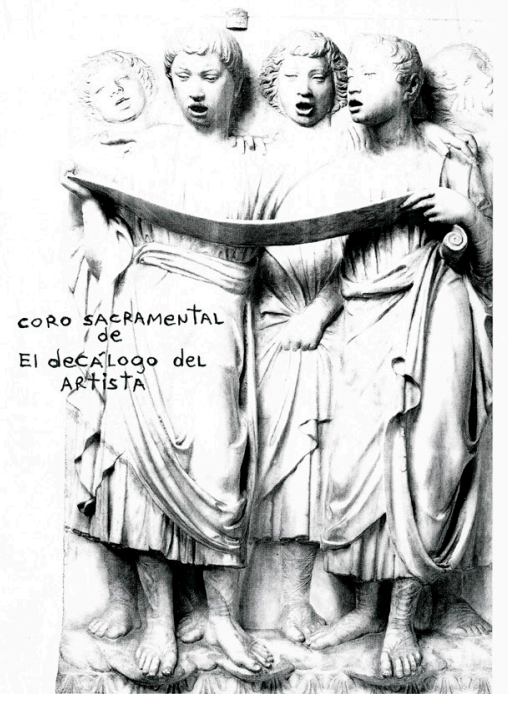

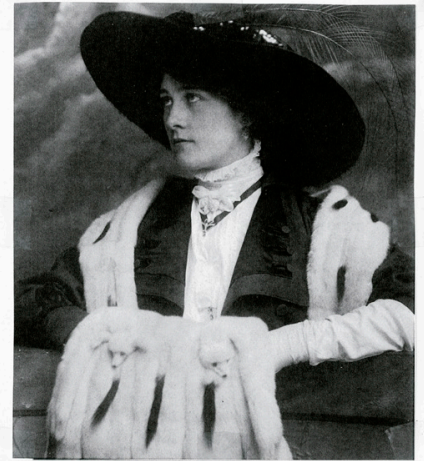

A Gabriela Mistrual

ique se CAIgA

la cordillera

de los Andes!

IMAGEN 3. Mistral y el coro

Un buen ejemplo de estas afinidades es la dedicatoria inicial a Gabriela Mistral [Imagen 3], que sirve como prólogo e ilustra el contrapunto y los complejos usos de la imagen presentes a lo largo de toda la obra. Recordemos brevemente las observaciones de Fontcuberta sobre el papel del artista y la función de las imágenes en la postfotografía: el primero como prescriptor de sentido y el último como valor de circulación por sobre el contenido. Al dedicarle su obra, Maquieira subraya la deferencia que tiene hacia la poeta y Premio Nobel chilena. No obstante, lo hace subvirtiendo el contenido y los sentidos de la imagen y el texto. Aunque Maquieira se la dedica, la imagen que utiliza no corresponde a una de Mistral, sino que está en resonancia con el otro texto de la página: “ique se caiga la cordillera de los Andes!”. En una entrevista, el poeta afirma que esta exclamación refiere a una anécdota de Mistral: en una ocasión, la autora se tomó una fotografía con una famosa actriz mexicana; mientras la sacaban, Mistral observó que la mexicana tenía puesto un gran sombrero. En ese momento comentó, según Maquieira, "si yo me pusiera ese sombrero grande, se caería la cordillera de los Andes" ("Diego Maquieira - El Annapurna", 10:15-10:55 min.). Así sea real o 
ficticia-difícil saber a ciencia cierta-, el efecto de la anécdota es el mismo: afirmando que sí, que se caiga, la cita exhorta a la subversión, a la alevosía. La foto que aparece en El Annapurna no representa ni a Mistral ni a la actriz: simplemente es una imagen a la que Maquieira quiere dotar de ese sentido. Al mismo tiempo, el texto "coro sacramental de El decálogo del artista" -en referencia al poema "Decálogo del artista" de Mistral-y la imagen en relieve del coro sugieren una invocación a las musas de la poesía que van a dar aire y la inspiración para arrancar el recorrido. Como en Warburg, la imagen del coro y la de la mujer no están atadas temporalmente por ningún tipo de causalidad o herencia en estilos - ¿qué tiene que ver el relieve de un coro con la fotografía de una señora de la alta burguesía a principios del siglo XX?-, sino por las fórmulas expresivas [Pathosformel], una memoria de las formas y los gestos a través de la historia -algo así como tropos o síntomas visuales que viajan a través del tiempo-.

Entrevistado por Diego Zúñiga, el autor resalta que la visión inicial de El Annapurna "fue la imagen de una diosa que baja a la Tierra y que visita unas tumbas" (párr. 2). La imagen mental, como visión en su estado más puro, tiene una función de guía en el proceso de búsqueda y selección de imágenes que serán incorporadas al proyecto; de modo que cada imagen podría ser considerada un paso más dentro del "arco narrativo", si se quiere, del libro. En su lectura de Los Sea Harrier, Rioseco hace una observación que ayuda a ilustrar y expandir este último punto. Según el crítico, Maquieira trabaja "la idea de una poesía del espectáculo, espectacular, que ocurre sobre un escenario preelaborado" (251), donde hay "una abundante colección de los más disímiles personajes [que] salen a escena [...] en una suerte de "aparente narratividad"' (252). Si hay una narratividad en El Annapurna, esta está relacionada con la llegada de la diosa, ya que en una de las primeras páginas del libro [Imagen 4] aparecen los versos: "Una diosa vagante / de la poesía / llamada Ombra / en un atravesar / de estrellas / baja a la tierra / a clavar sus / ojos", seguida por una serie de imágenes relacionadas al espacio, el cielo, el vuelo, los telescopios y su caída a la tierra, es decir, al escenario de su puesta en escena teatral. Pero, y esto hay que resaltarlo de forma vehemente, esta "narratividad" no es del todo lineal, estable, ni tan aparente, ya que se disgrega en todo momento. La diosa es un eco material (visual y temático) de la invocación de las musas en la dedicación a Mistral, pero esta aparece por lo menos diez páginas después de la invocación inicial. La idea aquí es crear vasos dialogantes, correspondencias visuales y temáticas a través del recorrido. Estas, sin 
embargo, son de una naturaleza sintomática o rizomática; en otras palabras, no siguen una lógica discursiva o sucesiva.

La diosa aterriza en Cuzco, foco espiritual del conocimiento ancestral según la visión de mundo de Maquieira. A partir de este punto, tanto la imagen de una mujer que aparece al costado de los versos citados más arriba (la materialización de la diosa) como la imagen de la piedra de los doce ángulos en Cuzco (las tumbas) que aparece poco después [Imagen 5], se convertirán en los dos motivos visuales más recurrentes de toda la obra. La aparición recurrente de los motivos ayuda a establecer ritmos fluctuantes, que enfatizan intensidades dentro de cada pasaje visual de la obra. Cada vez que reaparezcan, sin embargo, el mensaje lingüístico que llevan irá permutando, sirviendo como señales de ruta que deja nuestro poeta-director en el camino ${ }^{7}$.

7 En diferentes momentos la misma imagen de la diosa llevará escrito el mensaje: "Filum", "Clear all", "Freeze frame", "Mute", "Hubo un mientras quieto" y "Lucidus ordo". Por su parte, la foto de la piedra de los doce ángulos tendrá primero escrito el mensaje "Tumba de Cesar Vallejo" -acompañado por nombres de otros escritores y poetas latinoamericanos alrededor de la piedra central, todos forman parte del panteón de Maquieira-, sucesivamente esta también será la tumba "de la inocencia del surgimiento", "del lago Titi-caca", "de E=MC2", "de las cárceles secretas", "de la inteligencia artificial”, "de las 13 dimensiones de espacio tiempo", "de la NASA", "del reloj del tiempo", "de los átomos ultra fríos", "de la piedra de tope del tiempo", "de las nebulosas de contornos imprecisos", "del infinito menos 7 ", "de la resurrección cuántica", "de la medición del tiempo", "de los primeros clonados", "del principio de incertidumbre", "del universo en las cuerdas", "del muro de los lamentos" y por último será la "Piedra angular del horizonte de sucesos". Como es evidente, cada uno de estos mensajes se refiere a nociones científicas, religiosas, y cuando no, son alusiones al tiempo. 


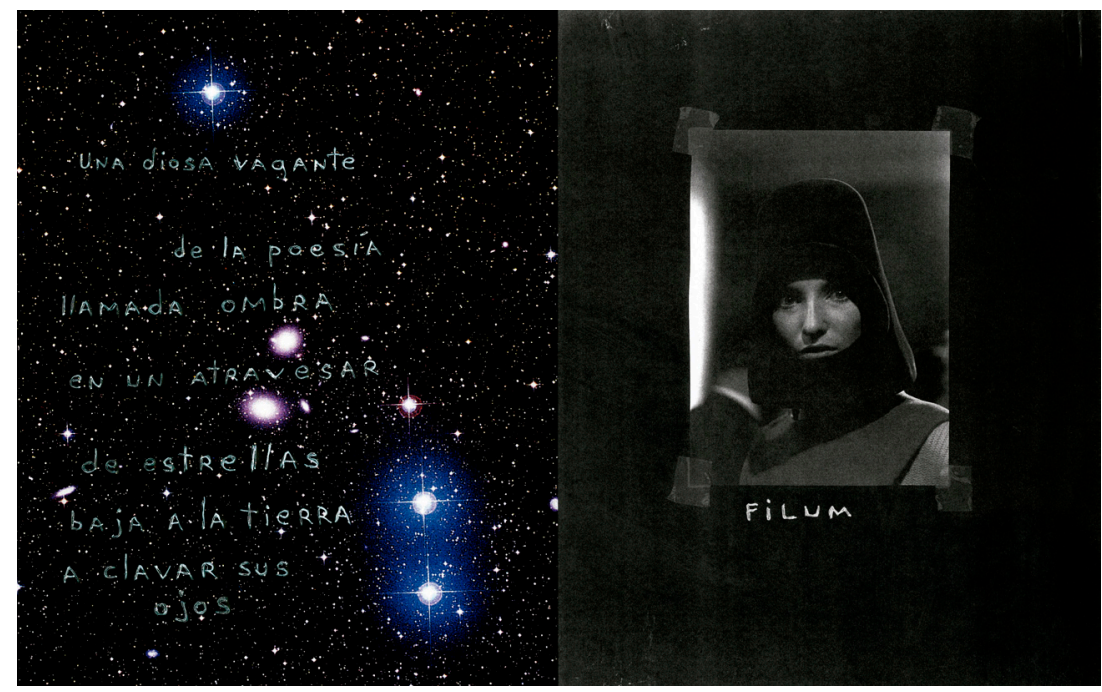

IMAGEN 4. Diosa Ombra
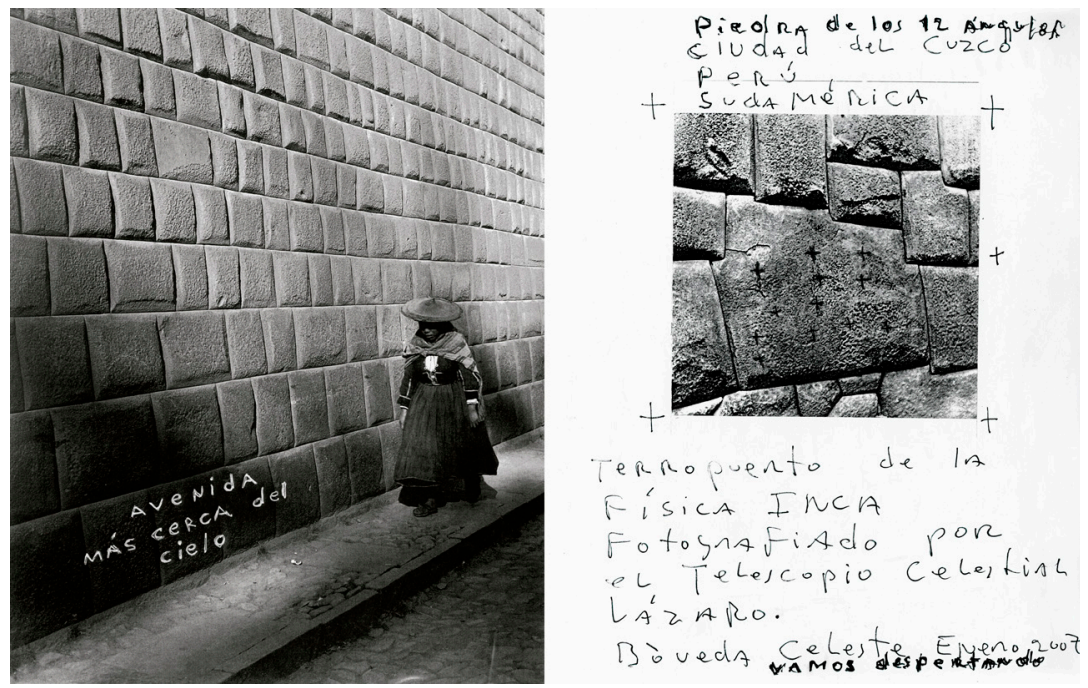

IMAGEN 5. Piedra de los doce ángulos 
Aunque es posible determinar núcleos temáticos en cada sección de $E l$ Annapurna, las imágenes que componen este libro son de una gama amplia: hay fotografías provenientes del espacio, de objetos de arte, de pinturas, de construcciones humanas y formaciones celestes, de cuerpos de mujeres y hombres, de la masa humana y personajes conocidos de la cultura, incluso de formas puras en la naturaleza. ¿Qué logra aquí, entonces, el poeta por medio de la aplicación de la técnica del montaje? Permite establecer y sostener un doble movimiento a lo largo del libro. Por un lado, observamos la fusión del espacio-tiempo en cada secuencia inmediata de imágenes. Esta fusión la hemos visto, por ejemplo, en el caso de la diosa Ombra y en Mistral y el coro: por más que cada imagen individual no tenga que ver la una con la otra temporal, secuencial o materialmente, el principio de similitud establece un diálogo entre ellas. Por otro lado, el montaje de secuencias extensas surte un efecto al que podemos llamar "aleph". Tal como en el célebre cuento de Jorge Luis Borges, el espectador percibe correspondencias a nivel micro (la fusión inmediata del espacio-tiempo) y a nivel macro (dentro de las secuencias enteras en las que se repiten versiones y motivos de los mismos elementos, pero en diferentes contextos) que dan pie a un sentimiento de simultaneidad. Es como si el espectador, al ocupar el lugar de la diosa, lo hiciera desde una temporalidad otra, no secuencial, sino sincrónica, omnipresente. De este modo, explora el mundo, pero lo hace desde un prisma que disgrega y está presente en todos los lugares al mismo tiempo.

Con frecuencia, el recorrido de El Annapurna apela a lo que el filósofo Jacques Rancière denomina en sus estudios sobre estética "la pensatividad de la imagen" (119). La pensatividad no es solo una propiedad inherente a la imagen -un elemento que surge de modo automático a partir del "silencio fotográfico o pictórico" (121)-, sino una operación relacionada a cambios de lógicas y estrategias propias de la mezcla de modos de representación: "La pensatividad de la imagen es el producto de ese nuevo estatuto de la figura que conjuga, sin homogeneizarlos, dos regímenes de expresión" (119). Para ilustrarlo, Rancière toma un ejemplo de $S / Z$ (1970) de Roland Barthes. En su lectura de Sarrasine (1830) de Balzac, Barthes resalta la última oración de la novela: "La marquesa se quedó pensativa" (cit. en Barthes 181). El adjetivo "pensativa" aquí hace dos cosas al mismo tiempo. Por un lado, es el final de la narración, así que debería ser el término de toda acción de la novela; sin embargo, hace lo contrario, la troca por otra lógica: "en el mismo momento que el relato llega a su fin, la 'pensatividad' 
viene a negar ese final; viene a suspender la lógica narrativa por una lógica expresiva indeterminada" (Rancière 119). Es decir que, aunque este sea el final concreto de la narración, la acción continúa, en suspenso, en el cambio de lógica. La pensatividad, en este caso, es producto del cruce de la literatura -lo narrativo, lingüístico y secuencial-con el campo visual que instaura esta última oración-imagen, como si la acción de la marquesa pensando se transformara en una pintura o fotografía y "nos la imagináramos pensando". Por esta razón, la acción continúa indefinidamente, suspendida en la imagen.

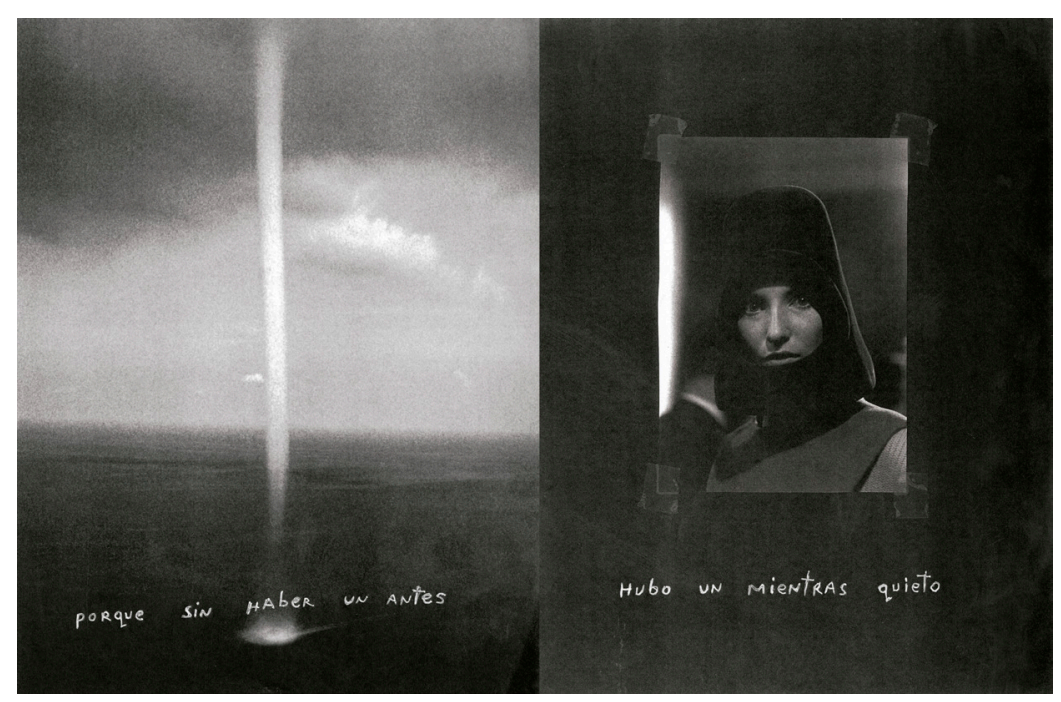

IMAGEN 6. Secuencia torbellinos 1 


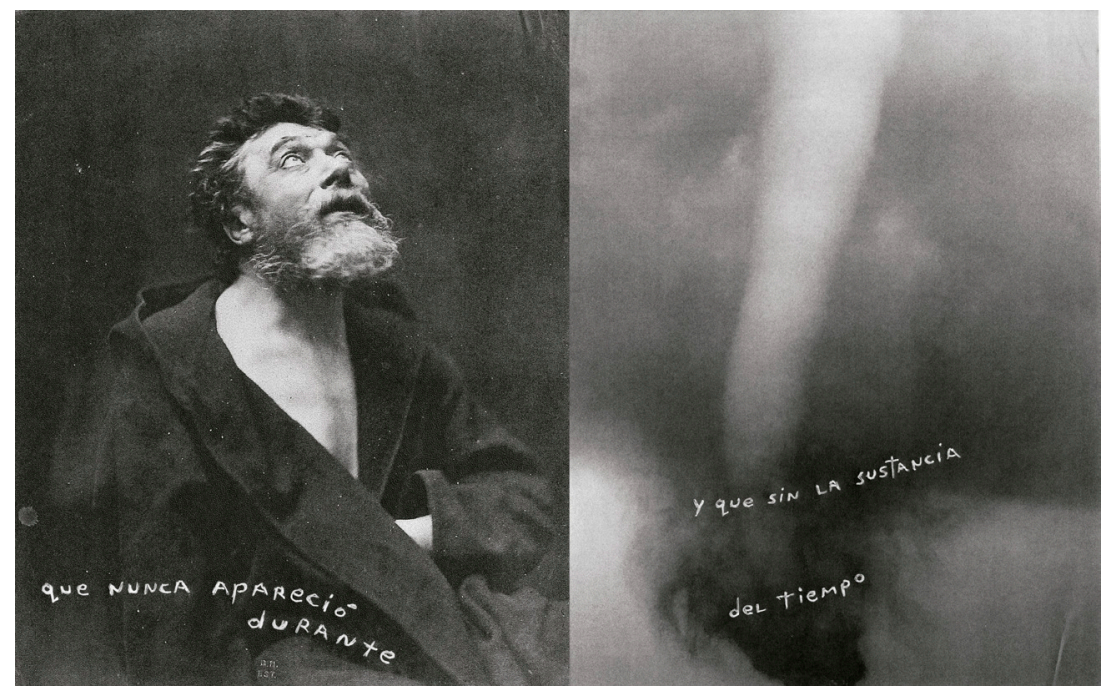

IMAGEN 7. Secuencia torbellinos 2
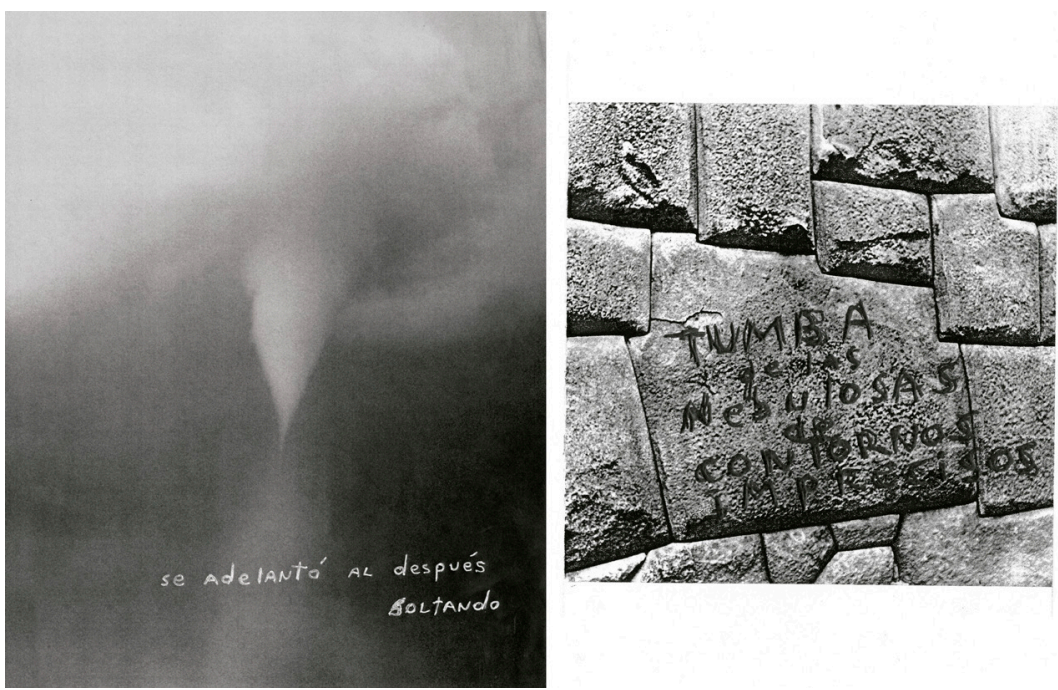

IMAGEN 8. Secuencia torbellinos 3 
Esta secuencia sucesiva [Imágenes 6, 7 y 8] puede ser considerada un montaje que ilustra la puesta en suspenso de lógicas que dan paso a la pensatividad de la imagen según Rancière. Lo primero que nota el espectador en estas páginas es la recurrencia de los torbellinos que, por su disposición en lados alternantes de la página y por la dimensión específica que tienen en cada imagen, dan la impresión de crear movimiento. Mientras tiene lugar esta acción concreta (o la ilusión de ella), las fotografías, no solo la de Nadar, sino las de los marcadores del motivo de la diosa (con el mensaje: Hubo un mientras quieto) y la de la tumba (de las nebulosas de contornos imprecisos) interrumpen la acción. Los versos escritos dicen: "porque sin haber un antes // Hubo un mientras quieto // que nunca apareció durante // y que sin la sustancia / del tiempo // se adelantó después / soltando". Estos hablan, por supuesto, sobre las paradojas de la eternidad del instante fotográfico. El efecto que crea la imagen de la diosa Ombra con el mensaje de "Hubo un mientras quieto" es uno de pausa, suspensión, dentro de la paradójica acción de la secuencia, como si en ese instante en el que mira la diosa se ensanchara el presente y volviera todas las acciones sincrónicas (como ocurre con la fotografía de Nadar, cuya mirada hacia arriba parece coincidir con el origen del torbellino a su lado). El cruce de la acción-visual con la detención lingüística del tiempo en el poema nos hace pensar en las zonas de indeterminación que son producto de la tensión de los elementos de representación que se encuentran ahí: ¿Dónde se ubica la diosa Ombra? ¿Quién es esta persona que aparece en medio de la secuencia? ¿Por qué está ahí y dónde está? ¿De dónde aparece esta voz que detiene la acción, que manipula e irrumpe en la imagen? ¿Tiene principio y fin este instante en suspenso o se ensancha el tiempo-espacio para incluirlo? 


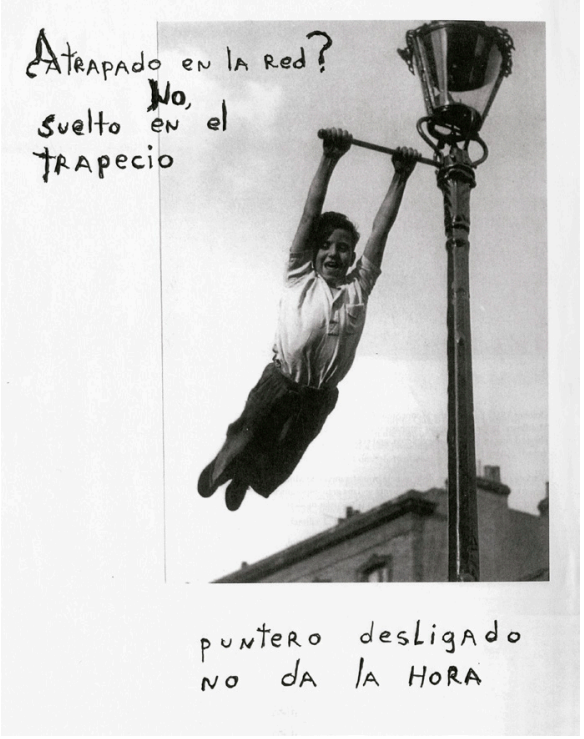

IMAGEN 9. "puntero desligado / no da la hora"

El motivo de la otra temporalidad será uno recurrente en el plano de las intervenciones textuales. Volvamos una vez más al trueque de lógicas de la pensatividad. En la fotografía de un chico colgando de un poste [Imagen 9], el plano visual muestra un chico meciéndose $y$, aunque está fijado en el eterno instante de la fotografía, de cualquier modo notamos que está en movimiento. En el plano de las intervenciones textuales leemos: “¿Atrapado en la red? / No / Suelto en el / trapecio // puntero desligado / no da la hora". Por un lado, establecemos la analogía visual entre el chico, el trapecio y el puntero: el chico cuelga (en el trapecio) como el puntero de cualquier reloj. El goce aparente en el gesto del muchacho se corresponde con la libertad de las ataduras de la red del tiempo a la que aluden los versos. Sin embargo, aunque sabemos que la imagen lo extrae del flujo temporal, a la vez, paradójicamente, lo fija. Así que, mientras los versos apelan a una lógica fuera (o más allá) del tiempo, esto entra choque con la lógica visual indeterminada entre la acción dentro de la imagen y la fijación material externa de la misma. 


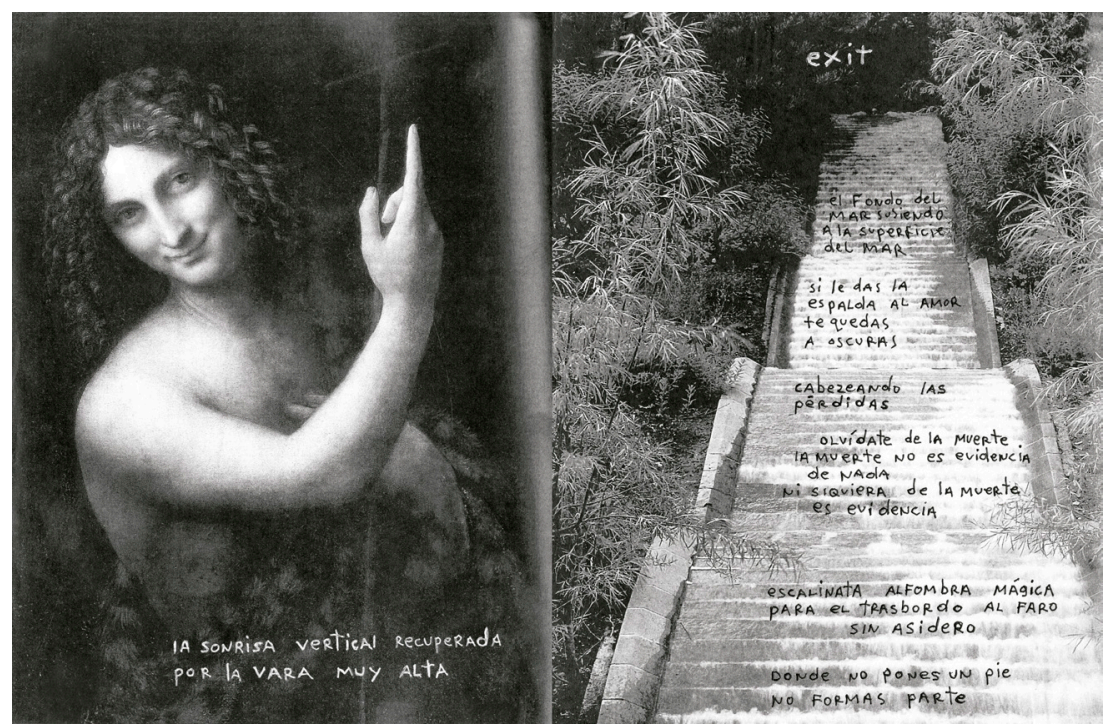

IMAGEN 10. "exit"

La mayoría de los textos verbales en El Annapurna se reducen a la extensión de aforismos, versos cortos o, como mucho, a una única estrofa. Sin embargo, hacia el final del recorrido encontramos un poema que llama la atención no solo por su extensión y temática, sino porque se enfrenta una vez más a la noción de un tiempo otro de la imagen [Imagen 10]. Lo transcribimos aquí en su totalidad (los versos que han sido añadidos a mano por el autor aparecen transcritos entre corchetes):

exit

el fondo del

mar subiendo

a la superficie

del mar

si le das la

espalda al amor

te quedas

a oscuras 


\author{
cabezeando las [sic] \\ pérdidas [idílicas] \\ olvídate de la muerte \\ la muerte no es evidencia \\ de nada \\ ni siquiera de la muerte \\ es evidencia \\ [sáltate el futuro \\ por el ojo de la aguja] \\ por escalinata alfombra mágica \\ para el trasbordo al faro \\ sin asidero \\ donde no pones un pie \\ no formas parte
}

Estos versos funcionan como un preludio al "retorno" de la diosa y al "final" de la obra, ya que aparecen a solo una página de la segunda y última vez que vemos de la imagen del portaviones. La intervención textual aquí se da sobre una foto en blanco y negro de una escalera de piedra por la que, aparentemente, desciende una cantidad significante de agua (¿o niebla?). Por medio de la combinación de velocidad del fílmico y el tiempo de apertura, la imagen logra congelar la caída al punto de crear un efecto de indiferenciación y de suspensión del tiempo. Para el espectador no es posible discernir exactamente qué es este objeto y si sube o baja, y es a partir de esta confusión inicial que el poema logra concretar su efecto. Desde el título y la primera estrofa del poema, la voz establece una inversión lógica de términos con relación a la direccionalidad. El fondo del mar sube a la superficie del mismo modo que en la fotografía no se diferencia en qué dirección fluye el agua. Por cierto, no hay que olvidar el hecho paradójico de que en la página anterior hay una copia de la pintura "San Giovanni Battista" (1513) de Leonardo Da Vinci, en la que aparece San Juan sonriendo misteriosamente y apuntando hacia arriba, hacia el cielo o a la correspondencia visual de la palabra "exit" en la próxima página. La primera coordenada espacial del poema tiene su correlato en la dimensión temporal, ya que establece una puesta en duda categórica sobre el tiempo, 
la muerte y los finales: "olvídate de la muerte / la muerte no es evidencia / de nada / ni siquiera de la muerte / es evidencia". Lo que permite poner en entredicho la eternidad de la muerte es justamente la capacidad de fijar el tiempo de la fotografía: "[sáltate el futuro / por el ojo de la aguja]". La "transfiguración del tiempo" a la que se refería la dedicatoria inicial se encuentra en plena función en este momento. La salida de El Annapurna no se encuentra en el futuro, sino en el eterno presente de la fotografía y la imagen. Podríamos suponer que todo esto apunta a una vuelta controlada a la "aparente narratividad" perdida de la diosa. En caso de que esto fuera cierto, ella volvería al centro de la escena, dispuesta a retornar nuevamente al cielo del que ha descendido.

Lo que nos lleva a un último problema. Al dar vuelta la hoja a la segunda aparición del portaviones observamos una imagen de la Tierra vista desde el espacio (como si la diosa hubiera vuelto al cielo), con el mensaje "la salida está por dentro. Ándate sin nada”, y en la página de al lado hay una fotografía de alguien en la playa tirando un manuscrito al aire [Imagen 11]. Este gesto sugiere un posible cortocircuito en la representación y la coexistencia de varias paradojas dentro del texto. La salida no está en la vuelta de la diosa a la bóveda celeste, sino en el interior, en la obra y la visión del poeta, y quizás, más aún, en ese adentro que logra captar el espectador para sí a lo largo de la lectura del libro. Si bien los versos que intervienen la imagen cancelan la interpretación de la vuelta de la diosa, la fotografía del manuscrito volando en el aire de la playa termina por delinear un fin abierto para la obra. 


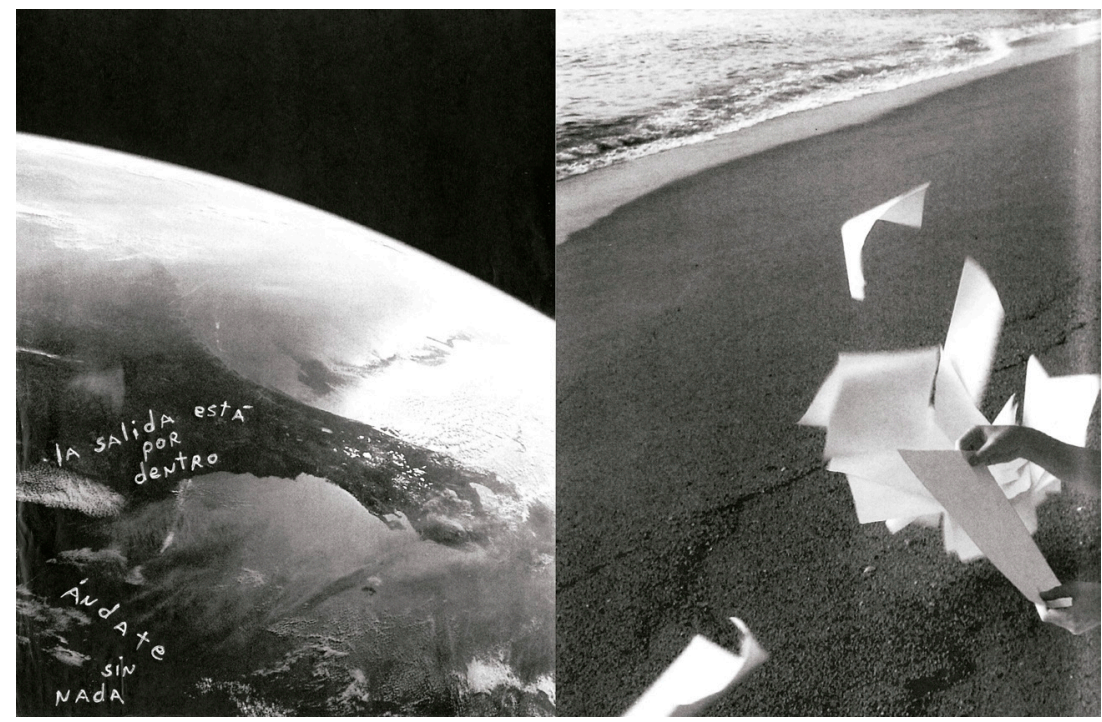

IMAGEN 11. "la salida está por dentro / ándate sin nada"

En relación con la proliferación de referencias culturales en Los Sea Harrier, Fontaine comenta que "[e]ste montaje que pareciera caótico, este girar desplazándose, sin centro, esconde algo así como mensajes cifrados que se presienten, pero no se revelan" (6). Algo del sentimiento de estar hurgando por un mensaje cifrado que nunca se revela también reverbera a lo largo de El Annapurna. Esto, sin embargo, quizás se debe a una diferencia clave entre el signo lingüístico y el signo visual. Recordemos que en la polisemia del signo lingüístico

[u]na palabra o comodín puede tener doble o triple fondo, pero sus ambivalencias son localizables en un diccionario, exhaustivamente enumerables: se puede ir hasta el fondo del enigma. Una imagen es siempre y definitivamente enigmática, sin "buena lección" posible. Tiene cinco mil millones de versiones potenciales (tantas como seres humanos), ninguna de las cuales puede imponer su autoridad (la del autor como cualquier otra). Polisemia inagotable (Debray 52). 
¿Qué enigma proponen entonces estas últimas imágenes? Por un lado, el poema se muerde la cola y termina en el mismo lugar donde empieza: en el cielo desde el que baja la diosa y el portaviones. Pero, por otro lado, también apunta hacia la derrota, la imposibilidad de escape y la suspensión del sentido, pues nunca se revela nada más que lo que siempre estuvo ahí. El poema, esa película en secuencia que el poeta-director ha compuesto para nosotros, culmina, pero al terminar se deshace inmediatamente y quiebra la ilusión. Ante la derrota de la palabra, la imagen se planta y nunca dice, sino que sugiere y desplaza el sentido hacia su polisemia inagotable.

¿A dónde nos llevan estas observaciones? En "The Necessity of Sense" (2006), Jean-Luc Nancy señala una ambigüedad constitutiva en torno a la palabra "sentido". En una primera definición, que adjudica a Hegel, el "sentido" ata un elemento en el proceso de significación a los medios de percepción ("los cinco sentidos"). En la segunda acepción, el proceso de significación está relacionado con la raíz de varias lenguas europeas de la palabra "dirección" o "camino". Por ello, el sentido puede ser, a la vez, percepción y camino, por lo que es preciso apelar de nuevo a la ambigüedad constitutiva del sentido, ya que, fundamentalmente, todo proceso de significación está en un estado de suspenso constante. En cuanto a los modos de percepción, Nancy añade: "The sensible is an erotics, not a semantics. An erotics represents not primarily a pathos of desire but a syntax of feeling" (113). Para trazar un puente que ayude a articular esta sintaxis, el filósofo apela al otro sentido de la palabra: el de dirección o camino. Esto significa que a pesar de estar en suspenso, el sentido de la poesía yace en un tránsito sensorial, en apuntar el "camino hacia". No existe tal cosa como la materialización de un sentido concreto, pues el sentido no es algo apropiable. Lo único que hay son percepciones, asociaciones, orientaciones que van sugiriendo un camino para lograr esa "syntax of feeling". La poesía es más un proceso que un fin. Por eso, el poema no procura un sentido lógico, sino rutas alternas, caminos que posibilitan un sentido otro para el lector.

Nancy pasa después al tema de la cesura. Un modo literal de entender la cesura en el poema es en el quiebre del verso, su interrupción, el pasar a la otra línea o el encabalgamiento. Esta acción está relacionada íntimamente con la poesía, porque, a diferencia del discurso (la prosa), que está diseñado en forma de línea, la poesía sobrevive en base a una tensión: la lucha entre un sentido que se quiere hacer y la necesidad de su deshacer. Lo que se juega en la cesura es ese deshacer del sentido, pero también en algo quizás más importante aún, su acentuación: "Then, sense stops being produced or 
occurring. But it is accented. It is tense: not in the sense of tending towards completion, but in the sense of tense to the point of breaking -indeed it does break. Cesura is the dismissal of sense" (Nancy 115). El Annapurna puede ser concebido como la búsqueda constante del quiebre literal y simbólico de la cesura, porque este es un poemario lleno de ellas: la cesura interna entre la imagen y el verso en cada página, la que ocurre entre las secuencias de imágenes, la cesura final del cierre.

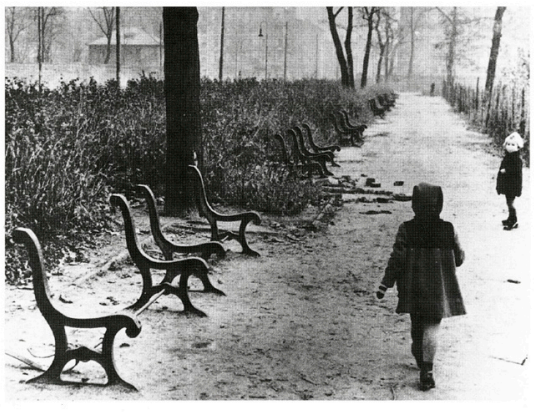

A comic seriows

IMAGEN 12. "a comic serious"

El cierre, o más bien la última imagen que cierra El Annapurna [Imagen 12], muestra a dos niños que caminan por una senda en medio del parque. Al costado hay muchos bancos que han sido reducidos a sus esqueletos de hierro. Un sentimiento de devastación y ruina palpable recorre el aire en esta imagen, como si hubiera sido tomada después de una guerra o un cataclismo. Aun así, la niña en la izquierda camina decididamente hacia el horizonte, mientras que la otra figura mira para atrás, hacia el lugar donde toman la 
foto. Este gesto de mirar hacia atrás sirve como cifra del proyecto de $E l$ Annapurna: sumergido en el camino, en la búsqueda, Maquieira se da vuelta atrás y nos apela con la mirada a seguirlo, a acompañarlo en un viaje por la erótica de los sentidos. Al pie de la imagen está escrito "A comic serious". Las composiciones poéticas de Maquieira podrían ser interpretadas bajo este lente: en el fondo de su dinámica lúdica, y en el goce en que siempre se regodea, hay un estrato de seriedad, una crítica real, donde se juega el futuro de la poesía. Para cerrar, dejamos reverberar en el aire una cita de Germán Cossio Arrendondo, tomada de su interpretación de La Tirana:

Finalmente y sin embargo, no se extraerá de todo lo dicho una consecuencia apocalíptica; al contrario, se cree que es justamente desde esta ruina gozosa desde la cual hay que articular una erótica de la escritura como una escritura de(sde) los sentidos. La trascendencia se podrá alcanzar, pero a través de una experiencia de la negatividad. La imagen de lo bello, por lo tanto, se encontrará entre las ruinas (32).

\section{BIBLIOGRAFÍA}

“\#30bienal (Programação) Diego Maquieira: Poesia fora de circuito". Youtube, 14 dic, 2012, consultado el 21 de noviembre de 2021, disponible en:

https://youtu.be/BHu1kr5TdqU

Ades, Dawn. Fotomontaje. Barcelona, Gustavo Gili, 2002.

Barthes, Roland. S/Z. Trad. Nicolás Rosa. Buenos Aires, Siglo XXI, 2004.

Bordwell, DAVID y Kristin Thompson. El arte cinematográfico. Una introducción. Buenos Aires, Paidós, 1995.

Cossio Arredondo, Germán. La ruina gozosa delen La Tirana o (la escritura fracasada de Diego Maquieira). Tesis de pregrado. Universidad de Chile, 2004.

Debray, RéGis. Vida y muerte de la imagen. Historia de la mirada en Occidente. Barcelona, Paidós, 1994.

Derrida, Jacques. Archive Fever. A Freudian Impression. Trad. Eric Prenowitz. Chicago, Illinois, University of Chicago Press, 1995.

"Diego Maquieira - El Annapurna". Laboratorio de Hipermedios. Facultad UC. Santiago de Chile, ago. 2013, disponible en: https://youtu.be/nPJFoniOXrI

Didi-Huberman, Georges. Ante el tiempo. Historia del arte y anacronismo de las imágenes. Buenos Aires: Adriana Hidalgo, 2011.

La imagen superviviente. Historia del arte y tiempo de los fantasmas según Aby Warburg. Madrid, Abada, 2009. 
Fontaine, Arturo. "El más pasado para la punta". El Mercurio. 23 nov. 2003, pp. 6-7.

Fontcuberta, Joan. La furia de las imágenes. Notas sobre la postfotografía. Barcelona, Galaxia Gutenberg, 2016.

GonzÁlez Ríos, Patricio. "Entrevista a Diego Maquieira: No me puedo quedar como Parra que se quedó atrapado en su propio sistema binominal de poesía y antipoesía”. El Mostrador. 8 nov. 2013, consultado el 21 de noviembre de 2021, disponible en: http://www.elmostrador. cl/cultura/2013/11/08/diego-maquieira-no-me-puedo-quedar-como-parra-que-se-quedoatrapado-en-su-propio-sistema-binominal-de-poesia-y-antipoesia/

Hidalgo, Patricio y Daniel Hopenhayn. Give me a Break: conversaciones con Diego Maquieira. Santiago de Chile, Editorial Universitaria, 2008.

Maquieira, Diego. El Annapurna. Santiago de Chile, D21, 2013.

La Tirana. Los Sea Harrier. Santiago de Chile, Tajamar Editores, 2012.

McBride, Patrizia. The Chatter of the Visible. Montage and Narrative in Weimar Germany. Ann Arbor, University of Michigan Press, 2016.

Mitchell, W.J.T. Teoría de la imagen. Ensayos sobre representación verbal y visual. Trad. Yaiza Hernández Velázquez. Madrid, Akal, 2009.

Nancy, Jean-Luc. "The Necessity of Sense". Multiple Arts. The Muses II. Simon Sparks (ed.), Stanford, Stanford UP, 2006, pp. 109-117.

RANCIÈRE, JACQues. El espectador emancipado. Buenos Aires, Manantial, 2008.

Rioseco, Marcelo. Maquinarias deconstructivas: poesía y juego en Juan Luis Martínez, Diego Maquieira y Rodrigo Lira. Santiago de Chile, Editorial Universitaria, 2014.

ZúÑIga, Diego. "Bienvenido, Diego". Qué Pasa. 22 ago. 2012, consultado el 21 de noviembre de 2021, disponible en:

http://www.quepasa.cl/articulo/cultura/2012/08/6-9272-9-bienvenido-diego.shtml/ 